\title{
Moral Responsibility and Environmental Conservation in Karamoja Mining Area: Towards a Religious Engagement
}

\author{
Margaret Ssebunya \\ Beatrice Okyere-Manu
}

\begin{abstract}
The consequences of the mining industry in Karamoja region have resulted into a serious environmental hazard to all forms of life in the area. For some reasons, efforts by the Ugandan government to respond to the environmental crisis seem inadequate. Investors in the mining sector and other stakeholders, particularly those who are directly affected, also seem not to be concerned with the dangers associated with the crisis. This situation raises a number of critical moral questions, for example, who is responsible for the degradation of the area? Why are the efforts of the government not yielding any results? Why are the locals who are bearing the brunt of the environmental crisis not showing any concerns? These and many more are the questions the article seeks to answer. Through the lens of the ethical theory of stewardship, the article challenges faith communities - particularly the two major religious groups in the area - Karamajong indigenous religion and Christianity - of the need to respond not only to humanity but also to the natural environment on which their existence depends. The article argues that responding to the environmental crisis should not be solely left to the government but rather is part of the moral and social responsibility of every individual including religious groups, in the area.
\end{abstract}

Keywords: responsibility, Karamoja, indigenous religion, morality, environment 


\section{Introduction}

A recent trip to the Karamoja region in northeastern Uganda revealed that mining activities are growing at a faster rate than before, following the discoveries of commercially viable mineral deposits. The discovery of the over 50 different minerals, such as gold, silver, copper, iron, gemstones, limestone and marble has attracted a number of investors - both foreign and local - to conduct mining activities in the area (Hinton et al. 2011: viii). One observes that the presence of the mining activities in the region has boosted the entire area of the onetime 'backward', 'primitive' and marginalized ${ }^{1}$ part of the country (Egeru et al. 2014:1). While there is evidence of the benefits resulting from mining in the region such as the boosting of the economy, employment of the local people and the general improvement of their wellbeing, one observes that there are also unintended consequences, impacting the the physical and natural environment such as deforestation, erosion of loose top soil, landslides, pollution and siltation of streams, as well as open pits (NEMA 2004: 105; Alliance for Responsible Mining 2011: 7; Villegas et al. 2012; Egeru et al. 2014). Despite the seriousness of the environment crisis in the region, efforts by the Ugandan government to respond to the situation have not yielded any sustainable results. The local communities who are directly affected by the crisis seem to have done little to respond to the crisis. In the meantime the unintended effects of the mining activities are threatening their very existence.

This situation raises a number of critical moral questions: why have the local inhabitants not responded to the crisis? Could it be that there is a measure of a dependency syndrome on the government, in particular, since, for a long time, the local people have been marginalized and the government is now trying to include them in the wider Uganda? Could it also be that the local people are ignorant of their rights and responsibilities because of the high illiteracy rate? Could it be that they are part of the problem and have therefore ignored it even though it is threatening their quality of life and very levels of subsistence? In an attempt to answer these questions, this article, through the lens of the ethical theory of stewardship, challenges the two major religious

${ }^{1}$ Karamoja is considered the poorest region in Uganda, and successive governments have viewed the inhabitants as 'backward' and 'primitive' Jessica Evans /Human Rights Watch. 2013. Available at: https://www.hrw.org/ report/2014/02/03/how-can-we-survive-here/impact-mining-human-rightskaramoja-uganda\#page. Accessed date 20 December 2017. 
groups in the area namely, the Karamajong indigenous religion and Christianity, about their responsibility to this crisis. Drawing on observation and available literature, the article also argues, that even though the two religions have diverse beliefs and practices with regard to their relationship with the environment, the common goal of conserving the environment is a strong commonality that can lead to the liberation and transformation of the environment in the entire region.

The article is divided into the following major sections. First, it analysis the environment crisis in Karamoja. Second, is a brief reflection on the Karamajong indigenous religion and its stewardship mandate. The third section offers a brief discussion of the Christian ecological obligation, and the fourth, presents an interfaith discussion of some practical possibilities on caring for the earth in order to contribute to the common good. This is followed by a conclusion.

\section{The Problem}

Karamoja is one of the most richly endowed mining regions in Uganda (Houdet et al. 2014: 1). Mineral discoveries in the region have attracted both foreign and local investors, whose activities have had serious unintended impacts on the natural environment. For example, land degradation is a common phenomenon, at not only the uncontrolled, unmonitored small-scale mining sites but also large-scale, controlled mining sites. In addition, there are a number of abandoned pits and vast stretches of abandoned land left bare (Hinton et al. 2011). Given that Karamoja is a dry area with limited access to water and rainfall, the abandoned pits are typically left unfilled, to become receptacles for water. In spite of the fact that such water is highly contaminated, people often use it for domestic purposes as well as for drinking water for their animals. Furthermore, the pits have become breeding grounds for mosquitoes, causing malaria, as they become filled with stagnant water. Meanwhile, malaria is known to be the leading cause of morbidity and mortality in Uganda ${ }^{2}$. The pits also serve as death traps, threatening the lives of community members, particularly children who go there frequently to play and swim.

${ }^{2}$ A study by Malaria Consortium shows that Uganda has the third largest malaria burden in Africa and the sixth largest in the world. Malaria Consortium in Uganda. 2011. http://www.malariaconsortium.org/pages/uganda.htm. 
Further, being an agro-pastoralist region (Egeru et al. 2014), the pits also pose a danger to wandering animals searching for water to drink.

Another major problem is the use of poor hazardous methods and technologies in the extraction of minerals. The use of poor mining technologies is not only limited to artisanal miners but also large-scale miners. For instance, Tororo Cement Limited (TCL) is one of the large-scale companies in the area, yet its mining activities show over-reliance on local manual labour (Houdet $e t$ al. 2014: 26). The reliance on local manual labour involves the use of primitive mining methods that are dangerous to the environment such as the lack of backfilling when digging pits in search of minerals. Villegas et al. (2012) list some of the impacts of primitive mining methods on the environment. They note that large-scale vegetation is often cleared for mineshaft constructions as well as for cooking and providing warmth in the mining camps. There is also the use of toxic materials such as cyanide and mercury, especially in gold processing, which are often released into waterways that contaminate the water. In addition, a number of mining activities take place in or near the few rivers and streams, leading to the removal and disruption of riverbeds and riverbanks because of intensive scooping, dredging, vacuuming as well as the physical removal of soil and rocks to access the deposits. This procedure is true to both large scale and small-scale mining, contributing to rivers overflowing their banks and causing flooding during rainy season.

A study by the National Environmental Management Authority indicates that lime extraction in the Karamoja region depend on the burning of limestone. At the same time, most of the kilns used are inefficient and of poor quality, leading to consumption of significant quantities of fuel in the form of wood, which has resulted in localized deforestation (2004: 105). The forest resource, which is a chief resource of the biotic community, is thus mercilessly exploited, thereby aggravating the environmental problem and contributing to the reduction in the full biological functioning of the ecosystem. Yet, as has been noted above, there are no efforts being made to reclaim such areas. Walking through the mining sites in Karamoja region, one is dumbfounded at the extent of the environmental degradation resulting from mining activities.

Furthermore, the extraction of gold from the mines takes place through an opencast system, which leaves behind large gaping pits as well as huge tracts of land cleared of vegetation. A study by Alliance for Responsible Mining (ARM) in Kaabong, Napak and Moroto districts also shows that mining activities have impacted cumulatively downstream, through siltation, 
creating health and safety hazards for animals and humans as well as impeding post-mining agricultural land-use (2011: 7). Already being a water deficient area, siltation of the limited water resources in Karamoja, has distressed the environment, including all its life support systems in the area, even further.

The rapid run-off in the deforested areas, siltation and pollution of rivers and streams as well as erosion of loose soil during the rainy season, and landslides, deny the local communities their right to a safe and healthy environment. Yet as can be noted, the right to a general satisfactory environment favourable to people's development is one of the rights clearly spelled out in the 1995 Uganda Constitution. Taking reasonable measures to prevent any form of environmental degradation in order to secure ecologically sustainable development is therefore fundamental. This is the responsibility of everybody in any community, including all faith communities, even amidst their diversity in values, beliefs and practices, in their variable relations with the environment.

\section{Karamajong Indigenous Religion and the Environment}

The Karamajong indigenous religion, just like any other African religion, holds the environment in high regard (Knighton 2005; Sherida et al. 2008; Magesa 1997). The environment is seen as the creation of a Supreme Being ${ }^{3}$ who sustains the universe and everything therein. The Supreme Being is not only a creator but also a controller and head of all things, is everlasting and present in all creation. Resultantly, the environment is treated with reverence as an embodiment of spirits. Certain aspects of the environment are considered sacred. Rivers, lagoons, groves, hills, animals, mountains and rocks are considered sacred and no person is allowed to tamper with them (Wilson 1989). In fact, people are prohibited from cutting trees, or even hunting in such sacred places lest the spirits in them are disturbed. Magesa believes that there is a force that holds together the 'universe to exist harmoniously and with all its constituent components' (2013: 633). The belief is that ancestral spirits live in such places, and, they must be respected, because they are considered as a means of connecting to the Supreme Being. Any disturbances might bring calamity to the community and may require the community to appease the

${ }^{3}$ The Supreme Being in the Karamajong indigenous religion is referred to as Akujŏ. 
ancestors. In this context, abusers are often severely fined. This belief and its related practices, are deeply entrenched in the lives of the traditional Karamajongs. As such, it has deterred them from abusing the environment and also safeguarded the sacred places and natural objects.

Asamoah Kumi (2013) notes that, 'the stringent adherence to these traditional orders goes a long way to preserve some rivers, trees ...' ' Taking this point further, Lloyd Henshey (2011), cited by Eneji et al., observes that '... many people believe[] that rocks, trees, streams, ponds and forests [are] the manifestation of the power of the Supreme Being and [see] these things as ideal places to meet their Supreme Being or the gods' (2012: 48). The perceived sacredness of these components of the environment shows not only the role of Karamajong indigenous religion in environmental conservation but also as an obligation to stewardship. It also demonstrates the co-existence between humanity and nature. This echoes the view of Mazrui (1986), when he says,

Indigenous African cultural and religious traditions promote[] a system that allow[] mutual co-existence between human beings and nature with God in between. There [is] a good deal of a culture of cohabitation and co-pasturing .

The main insight here is that none of the environmental components exist outside the creator. It also shows how the African traditional religious ideas (including the Karamajong indigenous religion) 'very much about relationships; whether with other living people, or with spirits of the dead, or with animals, or with cleared land, or with the bush' (Ranger 1988: 681). There is a close relationship not only with fellow humanity but also with the environment. The link between humanity and nature is maintained by the sacred, which occupies a prominent place in the traditional Karamajong society. By protecting sacred natural sites, such as wooded groves, local people derive spiritual rewards of serving their faith (Rutte 2011: 2). However, the current environmental degradation in Karamoja, suggests that the sacred groves are seriously threatened. Mining activities continue to threaten the Karamajong natural environment, and along with it, the indigenous mode of reverence of nature, and the accompanying practices related to the worship of the Supreme Being.

Another way the Karamajong indigenous religion use to protect and 
conserve some elements of the environment is through taboos. Taboos represent unwritten social rules that regulate human behaviour through control and constraint. Such constraints not only govern human social life, but may also affect, and are sometimes even used to directly manage, many constituents of the local natural environment (Adu-Gyamfi 2011: 147). These taboos are mainly linked to what the local community perceive as sacred spaces and sacred objects. For instance, trees are regarded as homes for ghosts, that bring rain (Moroto District Environment Office 2006: 28) and therefore should not be tampered with. This resonates with the belief that is a 'totemic ancestorhood' embedded in the environment, i.e. an 'indissoluble solidarity between humanity and the natural environment' (Murove 2009:320). Failure to uphold the sacred can bring calamity upon the community. To them, the sacredness within nature calls for the regular performance of rituals and sacrifices to ensure the continuance of a mutual relationship, and to avert any potential calamity, natural, or otherwise. It must be noted that the Karamojong resisted any foreign influence on them. They disregarded influences from both the foreign government and the Church. Therefore, the government and the church could not impose any demands on them until it had met their approval (Knighton 2005: 76). However, in terms of the degradation of the entire region, one wonders why they had been silent and not resisted the mining companies. Most possibly, because the companies did provide them with a source of income.

\section{A Brief Overview of Christian Ecological Perspectives}

The second major religious group in Karamoja is Christianity. As mentioned by a number of scholars, and similar to the Karamoja indigenous religion, Christianity too, adheres to the values related to the stewardship of the environment (Bugg 1991; Whelchel 2012; Kaoma 2013; Eammon 2014). This is a mandate bestowed upon humanity by God in the Bible. For example In Genesis 1 and 2, the environment, just like humanity, is seen as part of God's creation even though humanity was given the role of co-creation and domination. Undertaking the co-creation role, demands that believers from the Judaeo- Christian tradition, become good environmental stewards by taking care of the environment through the responsible management of its natural communities. Since the earth is the Lord's, humanity's duty is to serve and 
keep God's creation (Genesis 2:15). This biblical injunction has been explicated in terms of human stewardship of creation, 'on behalf of God', so to speak. Whelchel (2012) has argued that the "central essence of the biblical world view of stewardship is managing everything God brings into the life of humanity in a manner that honours God and impacts eternity'. It is a responsibility entrusted to every human being to ensure the well-being of the planet, other creatures, other human beings and future generations as well. Pope John Paul II reiterates this when he said:

Care for the environment is not an option but rather a responsibility of everyone. It forms an integral part of our personal life and life in society. Not to care for the environment is to ignore the Creator's plan for all creation and result in an alienation of the human person (1990: $15)$.

In his encyclical Laudato Si Pope Francis notes that genuine human development has a moral character. Such development presupposes full respect for the human person and shows concern for the world around us (2015: no.5). Pope Francis thus calls for a change in the Christian attitude towards the environment. He adds, 'together with our obligation to use the earth's goods responsibly, we are called to recognize that other living beings have a value of their own in God's eyes' (no. 69). Similarly, Roger Burggreave notes that the biblical conception of creation places humanity in an ethical relationship with creation. He maintains that 'human beings are not just put in the world as a "being among other beings" but created in an ethical relationship to the world'. They discover that they stand in an 'ethical bond' with creation (1991: 110). Such ethical bond places responsibility on humanity towards creation. In his study, The Steward: A Biblical Symbol Come of Age, Douglas John Hall (1990) develops a theology of stewardship that suggests that human beings are responsible for the whole earth. He contends that this responsibility includes the non-human as well as the human world. It is a responsibility that must seek to express itself in just and merciful political forms and must be exercised in the light of not only the immediate situation but of the near and distant future as well.

In the same vein, Ernst Conradie argues that Christianity 'offers ecological wisdom that may be crucial for responsible earth-keeping'. He notes that the Bible makes references to the 'earth, mountains, hills, air, waters, 
rivers, soil, trees, animals, birds, insects, etc.' in this regard. For him, reading the whole Bible through an ecological lens, reveals that the Bible is indeed 'filled to the brim' with ecological overtones. The earth and all its creatures are 'intimately interwoven with God's loving care for humanity' (2004: 127). Such care emphasizes a commitment for right relationships within the earth community. Yet in light of the ongoing environmental degradation in the Karamoja region, Christians in the region seem to have overlooked their mandate and have not responded adequately.

\section{Interfaith Perspectives on the Environment}

So far, we have argued that the environmental crisis in Karamoja is a serious problem that affects everyone, humans and animals alike. The consequences thereof constitute a major challenge for the Karamajong community. It has serious implications for the community, such as the diminishing of food sources for humans and animals, escalating poverty, starvation, threats to human habitation, and the deterioration of the health of the population in the region. As such, and given the reverence of nature by the religions subscribed to by the community, they are challenged to care for the community, both social and ethically.

Chirisa has argued that stewardship suggests, 'Taking responsibility for the environment to protect it from harm, to maintain it to be habitable, to keep its treasures and to preserve it for future generations' (2010: 44). It demands that human beings undertake environmentally responsible roles where they are able to promote, uphold and enhance the integrity of the natural environment in ways that tend and nurture it. Stewardship invites us to develop a true ethos and culture of compassion, care, empathy and solidarity towards the earth. It emphasizes developing life-caring values in bringing about deep change as a best practice to save our environment

Throughouthistory, religion has beeninstrumental in articulating worldviews that help instil moral values and laid foundations for mutual existence and sustenance of societies. It is seen as important to most African societies for it shapes their 'attitudes and behaviour regarding major issues such as social and environmental change' (Kaplan 2010: 263). It must be noted that most people are connected to one form of religious tradition or another (Bergmann 2009; Hitzhusen \& Tucker 2013) and religious principles are able to inform their relationship not only with one another but also with the natural environ- 
ment (Jenkins 2009). In this sense, one can shape perceptions of environmental problems in either 'positive' or 'negative' ways (Gerten \& Bergmann 2012).

In this context, we are of the view that a united and combined effort of the Karamajong religion and Christianity, in responding to the environmental crisis, will be an effective intervention for the following reasons. First, the natural environment in Karamoja is the major source of livelihood for all human and non-human inhabitants in the area. Yet, it is being threatened, and all experience the effects of this threat. Second, the communities in the area get their essential requirements of life, namely air, water, food and shelter from the environment. They should therefore ensure that their environmental resources are fit for human consumption. Third, besides being a natural resource for the basics of life's essentials, being a traditional rural area, some natural vegetation also serve as medicinal supplies in the treatment of sicknesses and diseases that affect community members. Leaves, plants, tree barks and roots are commonly used to treat common illnesses. Since there is a growing diminishing availability of these natural resources, due to the environmental crisis in the region, all people, regardless of their religious affiliation are affected. This calls forth a response from the religions. The religious groups with their already established audience in the local communities, have a mandate coming from their own beliefs, convictions, values, and practices, to be stewards of the environment. As such, the role of these religious groups in the region cannot be underestimated, because they have the power to influence how their followers should treat other humans and how they should relate to nature. They can thus be used as a tool for social mobilization towards the fostering of positive and caring practices related to the environment, and environmental change due to mining.

Lynn White has drawn our attention to the fact that, 'What people do about their ecology depends on what they think about themselves in relation to things around them. Human ecology is deeply conditioned by beliefs about our nature and destiny - that is, by religion' (1967: 1204). As such, the influence of religion on the conservation of the environment cannot be overemphasized. Edwin Eshun in a similar vein has argued for the importance of religious groups in the environmental conservation. He mentioned that 'considering the environment through the symbolic lens of religion may not only strengthen the relationship between humans and non-humans (plants and animals), but may also strengthen the existing relationship among members of the community who share the same beliefs about nature' (2011: 3). Taking Eshun's point 
further, and given the fact that the environmental crisis affect all in the area, their combined effort is likely to strengthen relationships, not only with regard to the care of the environment, but also socially across the religions. In this way the common challenge, may be a tool in building unity among the different religious groups as well as bringing about transformation in communities in Karamoja, with regard to their combined stewardship and care of the environment. Through dialogical cooperation, this may also address some remaining traditional hostility with regard to the arrival of Christianity in the region (cf. Jeane-Pierre 2013: 3).

\section{Some Practical Suggestions}

So practically what would it mean to cooperatively work toward being a community that care for and restore the environment, following its devastation after the mining companies' arrival? If there is to be environmental liberation of the Karamoja region then there has to be some practical suggestion for the interfaith engagement of the local religions. In this regard, it would be crucial to highlight the commonalities that exist in the religions, and that can be tapped into for the common good of the inhabitants of Karamoja. The commonalities can help foster mutual inter- and intra- religious dialogue, that could lead to harmonious relations. This is where the role of the leadership in each of the religions becomes important. Once there is understanding between the leadership, they will be able to influence their members to overcome the tension, scepticism and the cautious optimism that most likely exists. The two religious groups could thus play a role in shaping the views of their followers with regard to environmental change, thereby dispelling the dependency syndrome of waiting for the government to find solutions to the ecological problem in the region.

Both religions have the religious power to influence positive environmental change. For instance, in the Karamajong indigenous religion the traditional leaders who are also the custodians of the traditional beliefs, practices and indigenous environmental knowledge, have the power to institute social control mechanisms that can be used to regulate human activities related to the environment within their jurisdiction. The environmental knowledge of the Karamajong indigenous religion, and its intellectual heritage, can provide serve as a rich and insightful resource on environmental protection. Christian leaders on the other hand can use their pulpits to educate and influence the 
followers towards environmental conservation. They can base their conviction on the scriptures related to eco-justice, among other topics. In terms of the socalled creation imperative, the Christian is called to 'exercise dominion over creation, without being destructive' (Schaeffer 1979: 72). This also suggests that their silence, as evident in Karamoja region, can also be destructive to the environment and therefore be a symptom of their failure in their stewardship role.

Apart from influencing the local miners in doing all that they can to conserve the environment in the region, the two religious groups can come together as a coalition for environmental advocacy. As strong environmental advocates, they are likely to influence the government and policy makers in enforcing existing environmental conservation laws, to protect both the people and the natural environment in Karamoja.

\section{Conclusion}

The paper has examined the environmental problem in Karamoja. It has noted that one of the key contributing factors to this problem is the influx of miners and their activities in recent years. This is coupled with the government's laxity to enforce environmental laws and the lack of concern from the locals whose existence is being threatened. As a result, the paper has argued for the need to involve the stakeholders in addressing the environmental problem in the area. Having noted that one of the key but overlooked stakeholders are the religious institutions, the article has argued that despite the differences in teachings, values, beliefs and practices around issues of the environment, the two major religions in Karamoja (Karamajong indigenous religion and Christianity) must unite and respond to the crisis. This is because each of these religious groups do not only have power to influence its followers towards positive environmental change, but also their united effort in environmental advocacy, can influence the government and policy makers positively. The paper has noted that the starting point to realize such change is through genuine dialogue on the environmental crisis.

\section{References}

Adu-Gyamfi, Y. 2011. Indigenous Beliefs and Practices in Ecosystem Conservation: Response of the Church. Scriptura 107: 145-155. 
ARM 2011. Analysis for Stakeholders on Formalization in the Artisanal and Small-scale Gold Mining Sector Based on Experiences in Latin America, Africa, and Asia: Uganda Case Study. Alliance for Responsible Mining. Asamoah, K.M. 2013. Religious Environmentalism: The Church's Environmental Sustainability Paradigm. The Case of the Church of Pentecost in Ghana. European Journal of Business and Social Sciences 2.8: 59-76.

Bergmann, S. \& D. Gerten (eds.) 2009. Religion in Dangerous Environmental Change. Berlin: LIT Verlag.

Bugg, C. 1991. Stewardship. In Holman Bible Dictionary. Tennessee: Holman Bible Publishers.

Burggraeve, R. 1991. Responsibility for a New Heaven and a New Earth. Concillium 4: 107-118.

Chirisa, I. 2010. An Analysis of the Environmental Stewardship Concept and its Applicability in Peri-Urban Towns: Lessons from Epworth in Zimbabwe. Journal of Sustainable Development in Africa 12,4: 41-57.

Conradie, E. 2004. Towards an Ecological Biblical Hermeneutics: A Review Essay on the Earth Bible Project. Scriptura 85:123-135.

Eammon, M. 2014. Hearing the Cry of the Earth. Intercom Magazine. Available at: www.catholicbishops.ie/2014/09/01/intercom-september2014/. (Accessed on 23 December 2017.)

Egeru, A., C. Okia \& J. de Leeuw 2014. Trees and Livelihoods in Karamoja, Uganda. Evidence on Demand, UK. DOI: 10.12774/eod_hd.december 2014.egeruaetal.

Eneji, C-V.O. et al. 2012 Traditional African Religion in Natural Resources Conservation and Management in Cross River State, Nigeria.

Environment and Natural Resources Research 2. 4: 45-53.

Eshun, E. 2011. Religion and Nature in Akan Culture: A Case Study of Okyeman Environmental Foundation. Masters Dissertation. Ontario Kingston: Queens University.

Hall, D.J. 1990. The Steward: A Biblical Model Come of Age. Grand Rapids: WB Eerdmans.

Hitzhusen, G.E. \& M.E. Tucker 2013. The Potential of Religion for Earth Stewardship. Frontiers in Ecology and the Environment 11: 368-376. doi:10.1890/120322. Available at: http://www.esajournals.org/doi/abs/ $10.1890 / 120322$ ?af=R\&.

Gerten, D. \& S. Bergmann 2012. Facing the Human Faces of Climate Change. 
In Gerten, D. \& S. Bergmann (eds.): Religion in Environmental and Climate Change. London: Bloomsbury Academic.

Hinton, J. 2011. The Mining and Mineral Sector in Karamoja - Uganda:

Development Opportunities and Constraints. Kampala: Ecological Christian Organization.

Houdet, J. 2014. Cost Benefit Analysis of the Mining Sector in Karamoja, Uganda. Kampala, Uganda: IUCN Uganda Country Office.

Jenkins, W. 2009. After Lynn White: Religious Ethics and Environmental

Problems. Journal of Religious Ethics 37: 283-309. Available at: papers2:

//publication/uuid/B2441A10-F7C7-4903-96EC-778DF1C35BE1.

Jean-Pierre, K.B. 2013. The Contribution of the Sacred in Traditional African

Societies to Environment Ethics. Anthropology 1,3:1-4.

Kaplan, M.S. 2010. Will Religion Guide Us on Our Dangerous Journey? In

Moore, K.D. \& M.P. Nelson (eds.): Moral Ground: Ethical Action for a

Planet in Peril. San Antonio: Trinity University Press.

Kaoma, J.K. 2015. The Creator's Symphony: African Christianity, the Plight

of Earth and the Poor. Dorpspruit, Pietermaritzburg: Cluster Publications. Knighton, B. 2005. The Vitality of Karamojong Religion: Dying Tradition or Living Faith. Burlington: Ashgate Publishing Limited.

Magesa, L. 1997. African Religion: The Moral Tradition of Abundant Life. Maryknoll, New York: Orbis Books.

Magesa, L. 2013. What is not Sacred? African Spirituality. Maryknoll: Orbis Book.

Mazrui, A. Al'Amin 1986. The Africans: A Triple Heritage. New York and London: Little Brown and Co., and BBC Publications.

Moroto District Environment Office 2006. State of the Environment Report. Moroto, Uganda.

Murove, F.M. 2009. African Ethics: An Ontology of Comparative and Applied Ethics. Pietermaritzburg: University of KwaZulu-Natal Press.

NEMA 2004. State of Environment Report for Uganda 2004/05. Kampala: National Environmental Management Authority.

Pope Francis 2015. Encyclical Letter: Laudato Si, 24th May 2015. Available at: http://w2.vatican.va/content/dam/francesco/pdf/encyclicals/document s/papafrancesco_20 150524_enciclica-laudato-si_en.pdf. (Accessed on 28 December 2017.)

Pope John Paul II 1990. Peace with God the Creator: Peace with all of Creation. Message of Blessed John Paul II for the celebration of the World Day of 
Peace, January 1, 1990. Available at http://www.vatican. va/holy_father/ john_paul_ii/messages/peace/document s/hf_jpii_mes_1 9891208_xxiiiworld-day-for-peace_en.html. (Accessed on 28 December 2017.)

Ranger, T. 1988. African Traditional Religion. In Sutherland, S. et al. (eds.):

The World Religions. London: Routledge.

Rutte, C. 2011. The Sacred Commons: Conflicts and Solutions of Resource Management in Sacred Natural Sites. Biological Conservation 1-8.

Schaeffer, F.1970. Pollution and the Death of Man: The Christian View of Ecology. Wheaton, IL: Tyndale House.

Sheridan J.M. \& C. Nyamweru 2008. African Sacred Groves: Ecological Dynamics and Social Change. Oxford: James Curry.

Villegas, C., R. Weinberg, E. Levin \& K. Hund 2012. Artisanal and Smallscale Mining in Protected Areas and Critical Ecosystems Programme (ASM - PACE): Working Together towards Responsible Artisanal and Small-scale Mining. A Global Solutions Study. Estelle Levin Limited and WWF.

Whelchel, H. 2012. A Biblical View of Dominion: Stewardship Institute for Faith, Work and Economics. Available at: http://blog.tifwe.org/a-biblicalview-of-dominion- stewardship/\#sthash.GD4BP7Gn.dpuf. (Accessed on $21^{\text {st }}$ December 2017.)

White, L. Jr. 1967. The Historical Roots of Our Ecologic Crisis. Science 155: 1203-1207.

Wilson, B.K. 1989. Trees in Fields in Southern Zimbabwe: Special Issue on the Politics of Conservation in Southern Africa. Journal of Southern African Studies 15,2: 369-383.

Margaret Ssebunya Ethics Studies School of Religion, Philosophy and Classics Pietermaritzburg SsebunyaM@ukzn.ac.za

Beatrice Okyere-Manu Ethics Studies School of Religion, Philosophy and Classics

Pietermaritzburg Okyere-Manv@ukzn.ac.za 